\title{
Morphological analyses of Pseudoidium anacardii infecting brazilian cashew plants
}

\author{
Olienaide Ribeiro de Oliveira Pinto ${ }^{1}$, Celli Rodrigues Muniz ${ }^{1}$, José Emilson Cardoso ${ }^{1}$, Francisca Samara Assunção de \\ Oliveira ${ }^{1}$, Joilson Silva Lima ${ }^{1}$
}

${ }^{1}$ Embrapa Agroindústria Tropical, Rua Dra. Sara Mesquita, 2270, Pici, Fortaleza, Ceará, Brazil

Autor para correspondência: Celli Rodrigues Muniz (celli.muniz@embrapa.br)

Data de chegada: 01/06/2015. Aceito para publicação em: 31/05/2016.

$10.1590 / 0100-5405 / 2101$

\section{ABSTRACT}

Pinto, O.R.O.; Muniz, C.R.; Cardoso, J.E.; Oliveira, F.S.A.; Lima, J.S. Morphological analyses of pseudoidium anacardii infecting brazilian cashew plants. Summa Phytopathologica, v.42, n.3, p.257-260, 2016.

Pseudoidium anacardii has emerged as a serious threat to cashew crops in Brazil, where a considerable decrease in production has been attributed to this fungus. This work describes the morphology of the fungus involved in the infection process of Brazilian cashew cultivars to establish differences related to the severity of the disease. Symptomatic and asymptomatic plants of six different cashew cultivars had their leaves or flowers collected and processed for scanning electron microscopy. For the flowers, massive aggregates of erect conidiophores were observed growing side by side on the petals or inserted among the sepal hairs for all cultivars, except cultivar 'BRS 253'. For the leaves, mycelia covered their entire surface, and appressoria were well developed, multilobed, opposite in pairs or single, and deeply penetrated the epidermis. The asymptomatic leaves of the cultivar 'BRS 189 ' were fully covered by mycelium and conidiophores. These findings provide important information for the early detection of a fungal disease epidemic, which is important for monitoring its spread. The cultivars 'CCP 76' and 'BRS 189' presented infected flowers and leaves, but only the inflorescences were attacked in other genotypes. We suggest that variability in the anatomy of the cashew plant organs may be involved in plant mechanisms of defence, and this information can be employed in a cashew breeding programme.

Keywords: Oidium, cashew nut, fungi, Appressoria, obligate parasite.

\section{RESUMO}

Pinto, O.R.O.; Muniz, C.R.; Cardoso, J.E.; Oliveira, F.S.A.; Lima, J.S. Análise morfológica de Pseudoidium anacardii que infecta cajueiro no Brasil. Summa Phytopathologica, v.42, n.3, p. 257-260, 2016.

Pseudoidium anacardii tem surgido como uma séria ameaça à cultura do caju no Brasil, onde um declínio substancial na produção tem sido atribuído a esse patógeno. Esse trabalho descreve a infecção de folhas e flores de distintos clones de cajueiro atacados pelo fungo e demonstra diferenças relacionadas à severidade da doença e ao tipo de clone. Plantas sintomáticas e assintomáticas de seis tipos diferentes de clones de cajueiro tiveram folhas ou flores coletadas e processadas para microscopia eletrônica de varredura. Um denso agregado de conidióforos dispostos lado a lado ou inseridos entre os pêlos das sépalas foi detectado em todos os clones, exceto o clone 'BRS 253'. Nas folhas, uma extensa rede micelial recobrindo a superfície foliar foi observada e os apressórios mostraram-se bem desenvolvidos, multilobados, opostos em pares ou sozinhos, penetrando a epiderme das folhas. Folhas assintomáticas do clone 'BRS 189' mostraram-se cobertas por micélio e conidióforos. Esse dado é uma importante informação na detecção precoce da doença, especialmente em monitoramentos do progresso da doença. Os clones 'CCP 76 e 'BRS 189' apresentaram folhas e flores infectadas, enquanto outros tiveram apenas as inflorescências atacadas. Sugere-se que a anatomia de órgãos da planta seja variável de acordo com o clone investigado, e que essas diferenças possam estar envolvidas em mecanismos de defesa da planta e que essas informações possam ser utilizadas em Programas de Melhoramento do Caju.

Palavras-chave: Oidium, castanha de caju, fungo, Apressório, parasita obrigatório.

Ascomycete powdery mildew fungi of the order Erysiphales make up an important group of plant pathogens comprising more than 800 species that are responsible for the attack of approximately 1500 plant genera (1). Within the group, Pseudoidium anacardii (F. Noack) U. Braun \& R. T. A. Cook is a host specific pathogen that is observed as a powdery mildew, mainly in Anacardiaceae plants. It has emerged as a serious threat to cashew crops in Tanzania (8), Mozambique (10) and Uganda (5). Recently, $P$. anacardii has been implicated in both a considerable decrease in Brazilian cashew production and the substantial economic losses suffered by cashew growers, thus putting the future production of Brazilian cashew nuts at risk (7). The fungus damages different parts of the plant, including its leaves, inflorescences, maturi (green-cashews), apples and nuts (2). This obligate biotroph manifests itself as a powdery material on the leaves, flowers or fruits, from which it acquires nutrients through the epidermal tissue. The asexual conidiophores are wind-dispersed and eventually land on the surface of the plant to germinate afterwards (2).

The first stage in the morphological development of different powdery mildews is the development of the conidiophore after natural or artificial inoculation. An appressorial germ tube is generated a few hours after the conidiophore has landed and penetrated the leaf cuticle, thereby triggering the colonization process (9). Consulting the literature, the morphological details of these processes are only available for some genera, such as Oidium lycopersici Cooke \& Massee colonizing tomato plants (4) and Oidium heveae B.A. Steinm. in the rubber tree (6). In cashew plants, Uaciquete (10) used scanning electron microscopy to conduct artificial inoculations and investigate the infection process of young leaves. 
Symptoms associated with cashew plants include spots that are distributed across the upper side of the leaf. Eventually, the spots become larger and are covered by a greyish white powder. A blight in the inflorescences is also observed as the spread of a greyish white powder and their eventual premature fall (2). To date, there are no published studies that used scanning electron microscopy to describe the infection process of $P$. anacardii in the flowers and leaves of naturally occurring Brazilian cashew trees. Microscopic differences in the P. anacardii morphology among infected Brazilian cashew cultivars have not been determined. In this article, we present for the first time morphological aspects of $P$. anacardii infecting flowers and leaves of different cultivars of cashew plants from Ceará State, Brazil.

A total of six cashew cultivars (CCP 9, CCP 76, BRS 189, BRS 226, BRS 253 and CCP 1001), from the Embrapa Cashew Breeding Program were employed in this study. The plants were reared at the Experimental Research Station of Embrapa in Pacajus, Ceará, Brazil. For each cultivar, six samples consisting of leaves and flowers were collected from symptomatic and asymptomatic plants (5 plants each). Infected organs were immediately pre-fixed and processed for scanning electron microscopy with a Zeiss $940 \mathrm{~A}$ operating at a $15 \mathrm{kV}$ acceleration voltage.

Scanning electron microscopy of the infected flowers indicated the presence of elongated conidiophores in massive aggregations arising side by side on the petals (Figure 1) and inserted among the hairs of the sepals and the petals (Figures 1c, 1e and 1f). These patterns were observed on all cultivars, except 'BRS 253'. The sepals and petals of the flowers were extensively covered in hairs, which inhibited the observation of the fungus. However, a clear distinction could be made between the hairy-trichomes and the conidiophores because the hairytrichomes are pointed (Figure 1) and the conidiophores are rounded at the apex. The conidiophores each bear a single conidium (non catenescent) (Figure 1f) that is obvoid-ellipsoid, rounded at the apex and ranges from 20 to $45 \mu \mathrm{m}$ in length (Figures 1e and 1f). The conidia were observed to have smooth or wrinkled outer walls (Figures $1 \mathrm{~b}$ and 1f). Flower glandular trichomes were also detected and consisted of two columns with a four-celled glandular head (Figure 1d).

Mycelia covered the entire leaf surface and exhibited branches 3-4 $\mu \mathrm{m}$ in width (Figures 2a, 2b and 2c). Some leaf surfaces were completely covered by conidiophores, as were the flowers (Figure 2d). The conidia presented cylindrical to barrel-cylindrical shapes (Figures $2 \mathrm{~d}$ and $2 \mathrm{f}$ ). Newer hyphae were superimposed over older hyphae and formed elbow-like structures, which were frequently found across the infected surface of the leaf (Figures $2 \mathrm{f}$ and $2 \mathrm{~g}$ ). Appressoria were well developed, multilobed, opposite in pairs or single, and deeply penetrated the leaf epidermis (Figures 2f, $2 \mathrm{~g}$ and $2 \mathrm{i}$ ).

This is the first study reporting microscopy data on the infection of leaves and flowers of Brazilian cashew cultivars by the powdery mildew Pseudoidium anacardii. Initially, this disease was described solely as a foliar disease; however, with time, symptoms were detected in the inflorescences, maturi (young cashew fruit), apples and nuts, thus designating it as problematic and requiring control measures (2). Serrano et al. (7) demonstrated differences in the characteristics of the powdery mildew found in infected cashew nuts among distinct genotypes from the Embrapa Cashew Breeding Program, showing that the fungus action on cashew nuts was genotype-dependent and thus opening the door to the future selection of cashew plants based on their resistance or tolerance to this disease. Here, we collected flowers and leaves from the cultivars 'CCP 9', 'CCP 76, 'BRS 189', 'BRS 226', 'BRS 253' and 'CCP 1001'. In the field, the cultivars 'CCP 9', 'CCP 76, 'BRS 189' were found to be susceptible, presenting disease severity scores of 3 and 4, whereas the cultivars 'BRS 226', 'BRS 253' and 'CCP 1001' were found to be resistant, with disease severity scores of 1 and 2 . For the susceptible cultivars the fungus was widespread in both the flower and leaf samples in which mycelia,

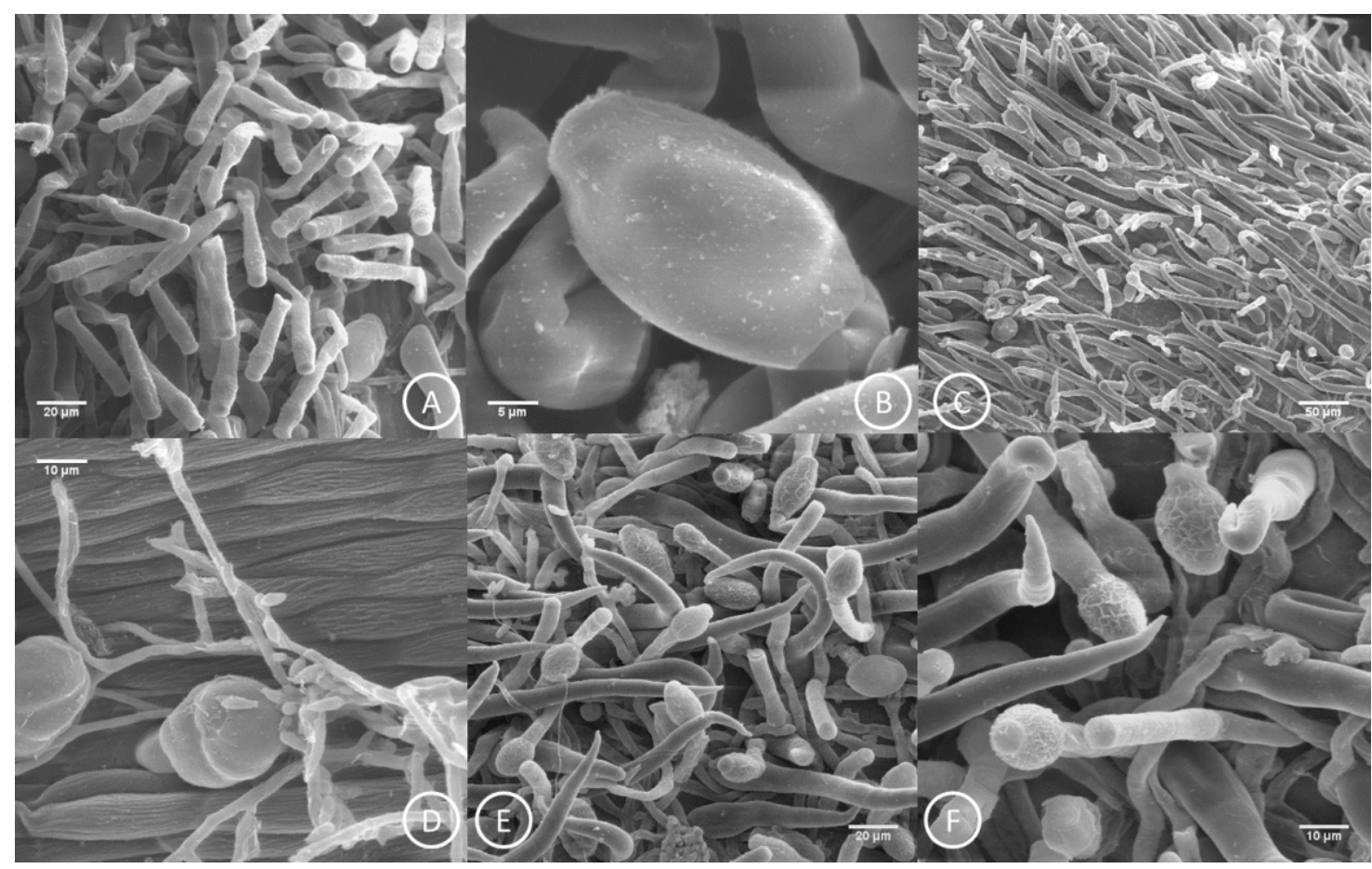

Figure 1. SEM images of naturally infected flowers of the cultivars 'CCP 9', 'CCP 76' and 'BRS 189': (a) Conidiophores, cultivar 'CCP 9', magnified 500x (b) Conidium, cultivar 'CCP 9', magnified 2000x (c) Conidiophores and hairy-trichomes, cultivar 'CCP 76', magnified 200x (d) Hyphae branching, magnified 1000x (e) Conidiophores and hairy-trichomes, magnified 500x (f) Process of conidiogenesis, magnified 1000x. 


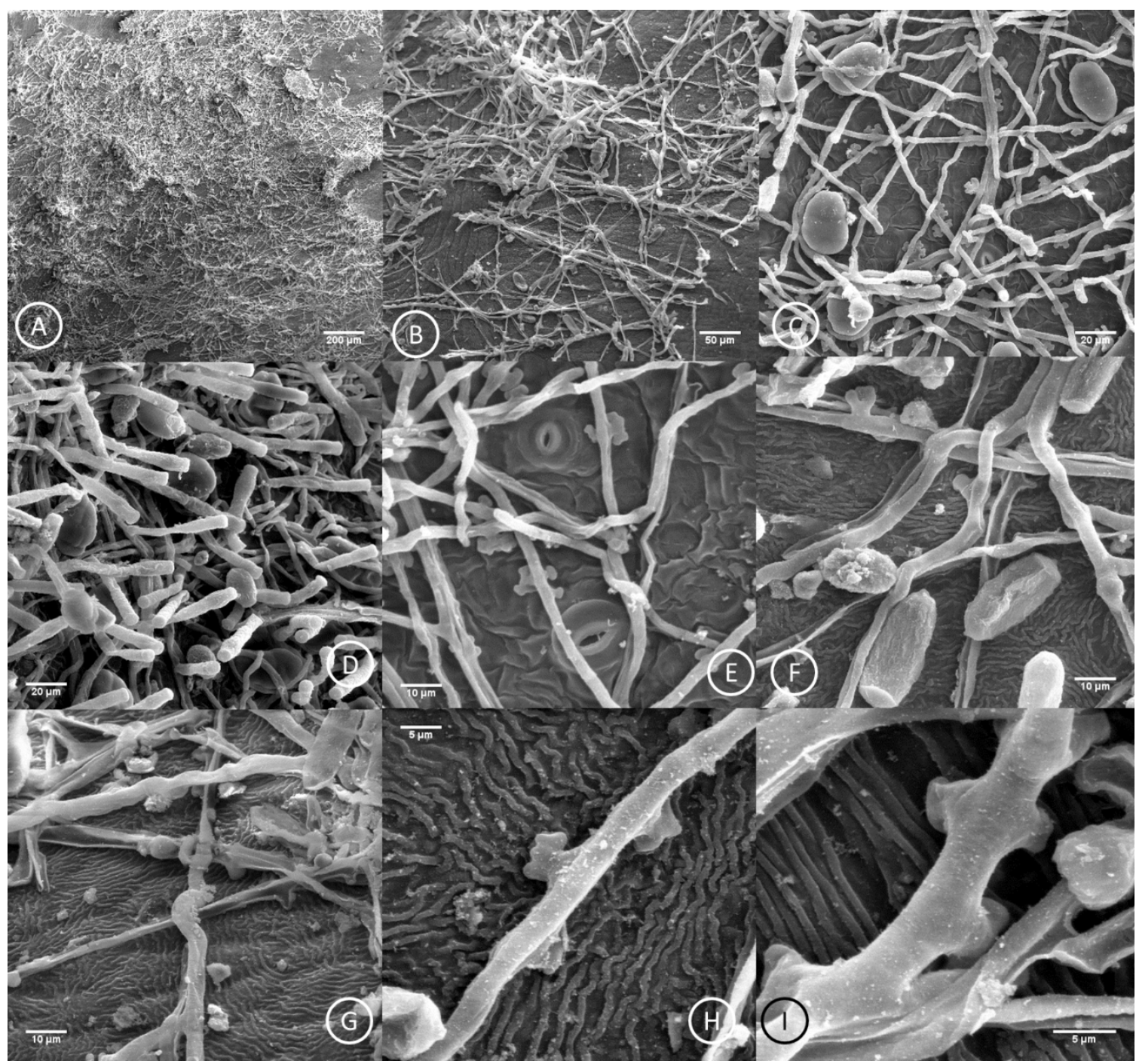

Figure 2. SEM images of naturally infected leaves of the cultivar 'CCP 76': (a, b, c) Mycelia covering the leaf surface, magnified 50x, 200x and 500x (d) Conidiophores, magnified 500x (e) hyphae and appressoria, magnified 1000x (f, g) penetration of the epidermis by the appressoria, magnified 1000x (h, i) details of the appressoria, magnified 2000x and 3000x.

appressoria, conidiophores and conidia were present. The preferred site of infection in the flowers was the sepals. It is noteworthy that $P$. anacardii and $O$. neolycopersici caused similar lesions on leaf blades and on sepals of tomato cultivars (3).

In contrast to the flowers, the leaves with hairless surfaces or "clear areas" allowed us to easily observe the different fungal structures, especially in cultivars ' $\mathrm{CCP} 76$ and 'BRS 189'. The different phenomena observed included the germination of the conidia, the formation of the appressorial germ tube, the production of conidia from conidiophores and the elongation of the hyphae across the leaf surface. However, unlike the flowers, the leaves were largely covered by hyphae, presumably due to the lack of hairs on the latter. The lack of hairs augments the nutrient uptake through the leaf epidermis, resulting in the dispersal of the hyphae across the entire leaf surface. Our findings are consistent with those of Uaciquete (10), who demonstrated the epiphytic growth of the fungal pathogen, the elongation of the secondary hyphae and the emergence of new conidiophores in the infected area.

In addition to the symptomatic leaves, leaves without symptoms were found to have fungal structures, especially leaves from the cultivar 'BRS 189', thus demonstrating that even when they are not diseased, some cashew genotypes may have the pathogen well established on their phyllosphere. This finding is important information for the early detection of the disease and for monitoring its progress. The cultivars 'CCP 76 and 'BRS 189' presented naturally infected flowers and leaves, whereas other genotypes only presented infected flowers. This is more evidence that some cashew genotypes are more resistant (i.e., less susceptible) to mildew attack.

Many of the morphological aspects of infection of cashew plants by $P$. anacardii are common to other species of Pseudoidium. Here, differences were examined in the morphology of infections in leaves and in flowers in general and in relation to different cashew cultivars. Furthermore, such differences were related to the degree and severity of the disease, as observed at the microscopic level, and again depended on the cashew cultivar studied. The monitoring of commercial cashew orchards can be conducted to prevent the widespread establishment of symptoms simply by a microscopic investigation of leaf samples. We suggest that the morphology of the plant organs of cashew plants 
may be involved in the defence and, therefore, the susceptibility of the plants to disease from powdery mildews. We also encourage further studies to establish the importance of the different organs and the mechanisms involved.

\section{REFERENCES}

1. Braun, U.; Cook, R.T.A. Taxonomic Manual of the Erysiphales (Powdery Mildews). St. Paul: APS Press, 2012.

2. Cardoso, J.E.; Viana, F.M.P.; Freire, F.C.O.; Martins, M.V.V. Doenças do cajueiro. In: Araújo, J.P.P. Agronegócio caju: práticas e inovações. Embrapa, Brasília, DF, Brazil, 2013, p. 217-238.

3. Jacob, D.; David, D.R.; Sztjenberg, A.; Elad, Y. Conditions for development of powdery mildew of tomato caused by Oidium neolycopersici. Phytopathology, v.98, n.3, p.270-281, 2008

4. Jones, H.E.; Whipps, J.M.; Thomas, B.J.; Carver, T.L.W.; Gurr, S.J. Initial events in the colonisation of tomatoes by Oidium lycopersici, a distinct powdery mildew fungus of Lycopersicon species. Canadian Journal of Botany, v.78, n.10, p.1361-1366, 2000.

5. Kiwuso, P.; Esegu, J.F.O.; Mujuni, D.; Epila-Otara, J. Key diseases and insect pests of cashew nut (Anacardium occidentale L.) in the Teso and
Lango farming systems of Uganda. In: Masawe, P.A.L.; Esegu, J.F.O.; Kasuga, L.F.J.; Mneney, E.E.; Mujuni, D. Proceedings of the Second International Cashew Conference. Kampala, Uganda, 26-29 April, 2010. Wallingford: CAB International, 2013.

6. Limkaisang, S.; Kom-un, S.; Furtado, E.L.; Liew, K.W.; Salleh, B.; Sato, Y.; Takamatsu, S. Molecular phylogenetic and morphological analyses of Oidium heveae, a powdery mildew of rubber tree. Mycoscience, v.46, p.220-226, 2005.

7. Serrano, L.A.L.; Vidal Neto, F.C.; Melo, D.S.; Cardoso, J.E. Influência do oídio nas castanhas de diferentes genótipos de cajueiro. Boletim de pesquisa e desenvolvimento, Embrapa Agroindústria Tropical, 76. Embrapa Agroindústria Tropical, Fortaleza, Ceará, Brazil, 2013.

8. Sijaonaa, M.E.R.; Clewerb, A.; Maddisonc, A.; Mansfielda, J.W. Comparative analysis of powdery mildew development on leaves, seedlings and flower panicles of different genotypes of cashew. Plant Pathology, Londres, v.50, p. 234-243, 2001.

9. Spanu, P.D. et al. Genome expansion and gene loss in powdery mildew fungi reveal tradeoffs in extreme parasitism. Science, v.330, n.6010, p.1543-1546, 2010 .

10. Uaciquete, A. Epidemiology and control of powdery mildew (Oidium anacardii Noack) on cashew (Anacardium occidentale L.) in Mozambique. 2003. 93f. Master diss. University of Pretoria, Pretoria, South Africa. 